\title{
Earthstars (Geastrum, Myriostoma) of the Hawaiian Islands Including Two New Species, Geastrum litchiforme and Geastrum reticulatum ${ }^{1}$
}

\author{
D. E. Hemmes ${ }^{2,4}$ and D. E. Desjardin ${ }^{3}$
}

\begin{abstract}
An updated, annotated list of earthstars found in the Hawaiian Islands is presented that includes 19 species of Geastrum and Myriostoma coliforme. Favored habitats for these gasteroid fungi include periodically wet windward coastal Casuarina groves, windward Leucaena thickets, and leeward coastal Prosopis groves. In contrast to these nonnative vegetation zones, earthstars such as Geastrum minimum, G. campestre, and G. corollinum are found also in largely native leeward montane Sophora/Myoporum forests, whereas Geastrum velutinum and $G$. reticulatum appear in montane native Acacia koa/Metrosideros forests. Eighty-two percent of the collections were made between September and February, although Geastrum triplex may be found earlier during the summer months. Two species, Geastrum litchiforme Desjardin \& Hemmes and Geastrum reticulatum Desjardin \& Hemmes, are described as new, accompanied by illustrations and comparisons with allied taxa. Geastrum xerophilum, originally published without Latin diagnosis, is formally validated. Specific collections are documented and island distribution and preferred habitats of the various species are listed. An artificial dichotomous key to aid in identification is provided.
\end{abstract}

An INITIAL REPORT on the earthstars of the Hawaiian Islands listed nine species of Geastrum in addition to Myriostoma coliforme and provided some information on their distribution in the Islands (Smith and Ponce de Leon 1982). During extensive collecting on all of the major Hawaiian Islands since then, under the auspices of a Biotic Surveys and Inventories Grant from the National Science Foundation, all 10 of those species were found plus 10 additional species of Geastrum including two that are described herein as new.

\footnotetext{
${ }^{1}$ This study was funded in part by a grant from the National Science Foundation Biotic Surveys and Inventories program (DEB-9300874) to D.E.D. and D.E.H. Manuscript accepted 4 February 2011.

${ }^{2}$ Department of Biology, University of Hawai'i at Hilo, 200 West Kāwili Street, Hilo, Hawai'i 96720.

${ }^{3}$ Department of Biology, San Francisco State University, 1600 Holloway Avenue, San Francisco, California 94132.

${ }^{4}$ Corresponding author (e-mail: hemmes@hawaii
}

Pacific Science (2011), vol. 65, no. 4:477-496

doi: $10.2984 / 65.4 .477$

(C) 2011 by University of Hawai'i Press

All rights reserved
Earthstars favor a number of alien or introduced vegetation types in the Hawaiian Islands, including the duff under the periodically wet Casuarina groves that line the windward shorelines, and under Cupressus. The coastal Casuarina groves near Hāna on Maui, those fronting Hālawa Valley on Moloka'i, and those at the mouth of Waipi'o Valley and lining the shorelines from Hilo to MacKenzie Park on Hawai'i Island are especially rich in these fungi. Leucaena thickets exposed to trade winds on the hillsides at Keolu Hills and Kailua/Lanikai on the windward coast of O'ahu, and the dry Prosopis pallida groves near the Puakō petroglyph fields at Kawaihae, Hawai'i Island, both support the growth of a number of species of Geastrum. Favored native forest habitats include the dry montane Sophora/Myoporum forests surrounding $\mathrm{Pu}^{\prime} \mathrm{u}$ Lā'au on the leeward side of Mauna Kea on Hawai'i Island; the mesic montane Acacia koal Metrosideros forests at Kōke'e on Kaua'i; and kipukas (islands of old forest) along the Saddle Road and in Hawai'i Volcanoes National Park on Hawai'i Island. An annotated list of all known species is provided, with distribution and favored habitats for each species. Descriptions and illustrations of two species new 
to science, Geastrum litchiforme Desjardin \& Hemmes and Geastrum reticulatum Desjardin \& Hemmes, and an artificial dichotomous key to aid in the identification of Hawaiian earthstars are included.

\section{MATERIALS AND METHODS}

The search for earthstars in various vegetation zones of the major Hawaiian Islands over the past $15 \mathrm{yr}$ was concentrated from September through February, the rainy season of each year. Major collecting sites included the following: the extensive trails in the Kōke'e State Park region on Kaua'i (mixed koa, $A c a-$ cia koa; karakanut, Corynocarpus laevigatus; and other alien species); Keolu Hills on O'ahu (haole koa, Leucaena leucocephala); the Hāna coastline (ironwood, Casuarina equisetifolia) and Polipoli Springs Road (black wattle, $\mathrm{Aca}$ cia mearnsii) on Maui; Pālā'au State Park on Moloka'i (Casuarina equisetifolia, Acacia mearnsii); Shipwreck Beach on Lāna'i (kiawe, Prosopis pallida); and MacKenzie Park (coastal Casuarina and coconut, Cocos nucifera), Pu'u Lā'au (māmane, Sophora chrysophylla; and naio, Myoporum sandwicense), $\mathrm{Pu}$ 'u Huluhulu (Acacia koa and sandawood, Santalum paniculatum), and the Puakō-Hāwī coastline (Prosopis pallida) on Hawai'i Island. Most sites on Hawai' $i$ Island were monitored on a monthly to bimonthly basis. Other areas on the major islands were searched, but the largest concentrations of earthstars were at these listed sites.

Both unexpanded and expanded fruiting bodies were photographed in the field and collected. Characteristics including whether the fruiting bodies were epigeous or hypogeous and had adhering debris were noted, and morphological details such as the structure of the peristome, size of the endoperidium, and number of rays were recorded. Species determinations were based on comparisons with pertinent literature (cited in the descriptions) and an examination of representative herbarium specimens. All specimens are deposited in the H. D. Thiers Herbarium at San Francisco State University (SFSU).

For each of the newly described species, spores were prepared for scanning electron microscopy (SEM) by dusting small portions of the gleba on double-sided adhesive tape on a specimen holder, coated with gold/ palladium using a sputter coater (Hummer 6.2), and examined with a FESEM (field emission SEM) (Hitachi S-800) operating at 15 $\mathrm{kV}$.

\section{RESULTS}

Nineteen species of Geastrum and Myriostoma coliforme are reported from the Hawaiian archipelago, of which eight represent new distribution records for the Islands, and two are described herein as new species. Records of collections of earthstars over the past $15 \mathrm{yr}$ show that $82 \%(320 / 388)$ of the recorded vouchers produce fruiting bodies from September through February. Geastrum triplex and G. saccatum were two exceptions, and these species were collected year-round.

ARTIFICIAL KEY TO HAWAIIAN EARTHSTARS

1. Endoperidium opening by numerous pores ............ Myriostoma coliforme

$1^{\prime}$. Endoperidium opening by a single apical pore $\ldots \ldots \ldots \ldots \ldots \ldots \ldots \ldots \ldots \ldots \ldots \ldots \ldots \ldots$

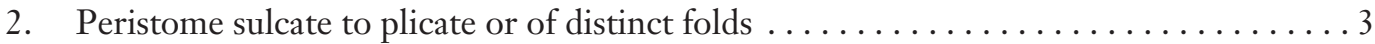

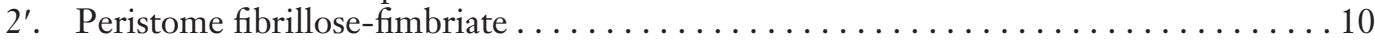

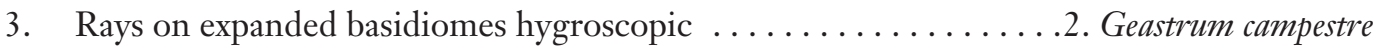

3'. Rays on expanded basidiomes not hygroscopic $\ldots \ldots \ldots \ldots \ldots \ldots \ldots \ldots \ldots \ldots$

4. Unexpanded basidiomes epigeous; exoperidial surface not adhering debris; endoperidial body sessile . . . . . . . . . . . . . . . . . . . . . . . . 5

4'. Unexpanded basidiomes hypogeous; exoperidial surface adhering debris; endoperidial

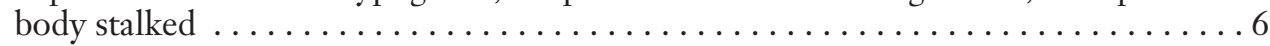


5. Exoperidial surface felted, smooth, reddish brown; peristome of distinct folds, indistinctly delimited .......................... Geastrum morganii

5'. Exoperidial surface covered with a reticulate network of raised hairs, orangish brown to brown; peristome plicate, distinctly delimited ....... 12. Geastrum reticulatum, n. sp.

6. Endoperidial stalk with a collarlike or ringlike apophysis; known in the Hawaiian Islands only from $\mathrm{O}^{\prime}$ ahu under haole koa .............. 16. Geastrum striatum

$6^{\prime}$. Endoperidial stalk lacking a collarlike or ringlike apophysis $\ldots \ldots \ldots \ldots \ldots \ldots \ldots 7$

7. Endoperidial body small, 6-14 mm diam. (avg. $8.8 \mathrm{~mm}$ ), glabrous; known in the Hawaiian Islands from coastal kiawe habitat . . . . . . . . . . 15. Geastrum schmidelii

7'. Endoperidial body larger, 10-27 mm diam. (avg. 15-18 mm), ornamented; habitat dif-

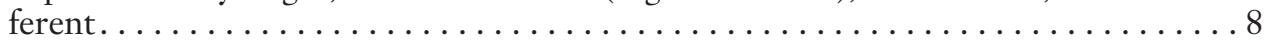

8. Base of endoperidial body vertically folded; endoperidium globose, surface with bluish gray tones . ......................... Geastrum pectinatum

8'. Base of endoperidial body smooth, lacking folds; endoperidium depressed-globose,

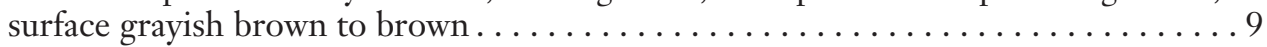

9. Surface of endoperidium coarsely roughened to verrucose (like sandpaper); common in coastal casuarina, cypress, or guava groves ............ 1. Geastrum berkeleyi

9'. Surface of endoperidium furfuraceous when young, glabrous in age; common in upland māmane-naio habitat . .................... 19. Geastrum xerophilum

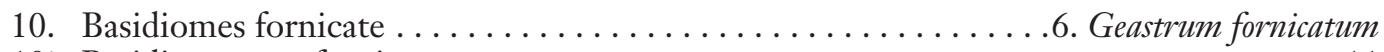

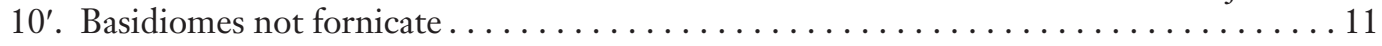

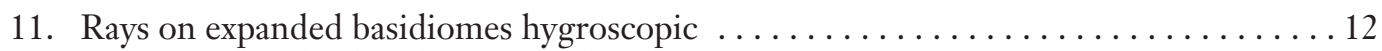

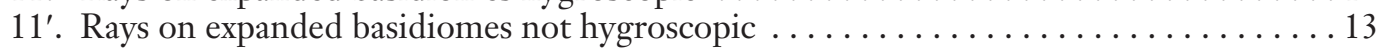

12. Unexpanded basidiomes hypogeous; exoperidial surface adhering debris ........ $\ldots \ldots \ldots \ldots \ldots \ldots \ldots \ldots \ldots \ldots \ldots \ldots \ldots \ldots \ldots \ldots \ldots \ldots \ldots \ldots \ldots \ldots \ldots$ Geastrum floriforme

$12^{\prime}$. Unexpanded basidiomes epigeous; exoperidial surface not adhering debris . . . . . . . . $\ldots \ldots \ldots \ldots \ldots \ldots \ldots \ldots \ldots \ldots \ldots \ldots \ldots \ldots \ldots \ldots \ldots \ldots \ldots \ldots \ldots \ldots$ Geastrum corollinum

13. Unexpanded basidiomes hypogeous; exoperidial surface adhering debris . . . . . 14

13'. Unexpanded basidiomes epigeous; exoperidial surface not adhering debris . . . . . . 16

14. Endoperidial body small, 4-12 mm diam. (avg. $7.9 \mathrm{~mm}$ ), with a well-developed stalk and apophysis; peristome distinctly delimited ........... 9. Geastrum minimum

14'. Endoperidial body larger, 10-24 mm diam. (avg. 17-20 mm), sessile or short-stalked;

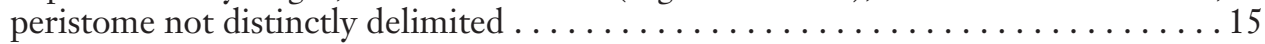

15. Pseudoparenchymatous layer of expanded rays pink to reddish brown; endoperidial body short-stalked at maturity; known in the Hawaiian Islands only from composted

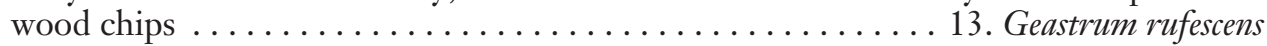

$15^{\prime}$. Pseudoparenchymatous layer of expanded rays tan to beige or pale ochraceous; endoperidial body sessile; known from coastal coconut and Casuarina groves . . . . . . . . ................................. Geastrum fimbriatum

16. Basidiomes arising from extensive subiculose mycelium, in clusters on scenescent coconut fronds or composted wood chips ............. 7. Geastrum javanicum

16 . Basidiomes not arising from subiculose mycelium; habitat variable $\ldots \ldots \ldots \ldots \ldots 17$

17. Surface of unexpanded basidiomes covered with dark brown pyramidal tufts of fibrils in an areolate pattern resembling a lychee fruit; peristome indistinctly delimited .... $\ldots \ldots \ldots \ldots \ldots \ldots \ldots \ldots \ldots \ldots \ldots \ldots \ldots \ldots \ldots \ldots \ldots \ldots$. Geastrum litchiforme, n. sp. 
17'. Surface of unexpanded basidiomes smooth, velutinous, or scaly, lacking pyramidal

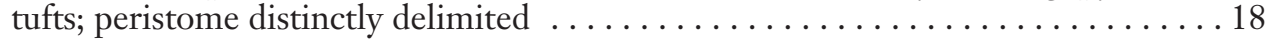

18. Pseudoparenchymatous layer of expanded rays usually breaking at maturity to form a cup around base of endoperidial body; surface of unexpanded basidiomes covered with small brown scales . . . . . . . . . . . . . . . . 17. Geastrum triplex

18'. Pseudoparenchymatous layer not breaking to form a cup around endoperidial body; surface of unexpanded basidiomes glabrous to minutely felty or velutinous . . . . . 19

19. Surface of unexpanded basidiomes velutinous, dark brown; pseudoparenchymatous layer of expanded rays with a pink hue ............ Geastrum velutinum

$19^{\prime}$. Surface of unexpanded basidiomes glabrous to minutely felted, ochraceous to pale brown; pseudoparenchymatous layer of expanded rays pale ochraceous to pale brown . . . . . . . . . . . . . . . . . . . . . . . . . . . . . . 14. Geastrum saccatum

\section{TAXONOMY}

1. Geastrum berkeleyi Massee, Ann. Bot., Lond. 4:79, 1889.

Descriptions: Sunhede (1989), Pegler et al. (1995), Calonge (1998), Hemmes and Desjardin (2002).

SPECIMENS EXAMINED: Hawai'i Island: Hilo, 333 Kalili Street, scattered in leaves under Psidium cattleianum, 7 November 2000, DEH 2019; Hilo, University of Hawai'i campus, Loulu Garden, August 1995, DEH 441; Hilo, Keaukaha, scattered in duff under $\mathrm{Ca}$ suarina equisetifolia, 21 October 2001, DEH 2168; same location and habitat, 3 July 2004, DEH 2489; Hilo, Lili'uokalani Park, scattered in duff under Casuarina equisetifolia, 23 September 2005, DEH 2588; same location and habitat, 11 December 2005, DEH 2607; same location and habitat, 16 January 2007, DEH 2680; Lava Tree State Park, scattered in duff under Casuarina cunninghamiana, 14 November 2001, DEH 2190; MacKenzie Park, scattered in duff under Casuarina equisetifolia, 15 February 1994, DEH 423; same location and habitat, 16 January 2000, DEH 1924; same location and habitat, 18 April 2000, DEH 1947; same location and habitat, 19 February 2001, DEH 2069; same location and habitat, 12 October 2001, DEH 2152; same location and habitat, 12 October 2001, DEH 2153; same location and habitat, 14 November 2001, DEH 2191; same location and habitat, 16 November 2001, DEH 2197; same location and habitat, 22 January 2002,
DEH 2248; same location and habitat, $31 \mathrm{Au}-$ gust 2002, DEH 2314; same location and habitat, 18 September 2002, DEH 2333; same location and habitat, 15 September 2005, DEH 2581; same location and habitat, 1 February 2007, DEH 2688; Pāhoa, Mike Au's farm, scattered in duff under Cupressus lusitanica, 16 November 2001, DEH 2192; same location and habitat, 10 November 2000, DEH 2022.

Notes: Geastrum berkeleyi is found in scattered groups in a variety of habitats including under coastal ironwoods (Casuarina equisetifolia), groves of Portuguese cypress (Cupressus lusitanica), and thickets of strawberry guava (Psidium cattleianum). The unexpanded fruiting body is hypogeous, depressed-globose, and the exterior is encrusted with debris. The exoperidium splits into 5-9 rays that are usually arched. In Hawaiian specimens, the endoperidium averages $17.1 \mathrm{~mm}$ in diameter (9-23 mm; 63 specimens) and is depressedglobose, brown to grayish brown, verrucose to coarsely roughened, stalked with a distinct apophysis, and topped with a conical, plicate peristome. This species can readily be distinguished from $G$. pectinatum, a superficially similar species that has a more globose, bluish gray endoperidium that is covered with a whitish pruina and has folds on the lower surface that can be seen easily with the naked eye. Hemmes and Desjardin (2002) were the first to report $G$. berkeleyi from the Hawaiian Islands, where it is relatively common on Hawai'i Island. 
2. Geastrum campestre Morgan, Am. Nat. 21:1027, 1887.

Descriptions: Sunhede (1989), Pegler et al. (1995), Calonge (1998).

SPECIMENS EXAMINED: Hawai'i Island: MacKenzie Park, solitary in duff under Casuarina equisetifolia, 14 November 2001, DEH 2188; Pu'u Lā'au, scattered on soil under Sophora-Myoporum, 24 September 1996, DEH 1258; same location and habitat, 27 August 1997, DEH 1517; same location and habitat, 23 September 1997, DEH 1534; same location and habitat, 21 October 1997, DEH 1604; same location and habitat, 21 October 1997, DEH 1605; same location and habitat, 21 October 1997, DEH 1796; same location and habitat, 15 July 2009, DEH 2798; same location and habitat, 10 August 2009, DEH 2811.

Notes: Geastrum campestre is one of the hygroscopic species, along with G. corollinum and $G$. floriforme, commonly found in the dry montane māmane-naio habitat at high elevations on the leeward side of Mauna Kea. In $G$. campestre, the size of the endoperidium varies widely (5-18 $\mathrm{mm}$ diam.; avg. $11.8 \mathrm{~mm}$; 40 specimens) and the peristome is sulcate to plicate. Geastrum corollinum and G. floriforme are smaller species with fimbriate-fibrillose peristomes. Geastrum campestre was previously recorded from the Hawaiian Islands by Gilbertson et al. (2001) and Hemmes and Desjardin (2002).

3. Geastrum corollinum (Batsch) Hollós, Gasterom. Ung. 65:154, 1904.

Descriptions: Sunhede (1989), Pegler et al. (1995), Calonge (1998), Hemmes and Desjardin (2002).

SPECIMENS EXAMINED: Hawai'i Island: Pōhakuloa, scattered in dirt under Myoporum, 2 December 2000, DEH 2041 and DEH 2042; Puakō, scattered in soil under coastal kiawe, Prosopis pallida, 19 March 2007, DEH 2689; same location and habitat, 22 December 2007, DEH 2730; same location and habitat, 7 February 2009, DEH 2791; same location and habitat, 19 February 2009, DEH 2796; same location and habitat, 10 August
2009, DEH 2812; Pu'u Lā'au, scattered under Sophora-Myoporum, 23 September 1997, DEH 1535 and DEH 1536; same location and habitat, 21 October 1997, DEH 1565 and DEH 1566; same location and habitat, 2 January 1998, DEH 1798.

Notes: Geastrum corollinum is a small, strongly hygroscopic species with fimbriatefibrillose peristome found in dry māmanenaio forests on the leeward slopes of Mauna Kea on Hawaili Island and in dry leeward coastal kiawe forests (Prosopis pallida). The species differs from the very similar G. floriforme in being epigeous, strongly hygroscopic, and thus curled in tight little balls with no adhering debris on the exterior mycelial layer. Geastrum floriforme is approximately the same size, only slightly hygroscopic, but is typically hypogeous and has conspicuous adhering debris on the outer surface. The Hawaiian specimens of $G$. corollinum are typically smaller than those reported from Europe and North America, with endoperidia averaging $10 \mathrm{~mm}$ in diameter (6-12 $\mathrm{mm} ; 16$ specimens). The species was reported from Hawai'i Island by Gilbertson et al. (2001) and Hemmes and Desjardin (2002) and from O'ahu by Smith and Ponce de Leon (1982; as Geastrum recolligens (With.) Desv.).

4. Geastrum fimbriatum Fr., Syst. Mycol. 3:16, 1829.

Descriptions: Sunhede (1989), Pegler et al. (1995), Calonge (1998), Hemmes and Desjardin (2002).

SPECIMENS EXAMINED: Hawai'i Island: Lili'uokalani Park, Hilo, clustered to scattered in Casuarina duff, 13 September 2005, DEH 2574; MacKenzie Park, scattered in duff under Casuarina equisetifolia, 29 November 1994, DEH 650; same location and habitat, 24 November 1998, DEH 1761; same location and habitat, 18 April 2000, DEH 1948; same location and habitat, 6 October 2005, DEH 2594; same location and habitat, 29 October 2005, DEH 2601; same location and habitat, 13 December 2005, DEH 2611; MacKenzie Park, scattered in coconuts and coconut fronds under Cocos nucifera, $7 \mathrm{No}$ vember 2000, DEH 2020; same location and 
habitat, 16 November 2001, DEH 2196; same location and habitat, 11 December 2001, DEH 2213; same location and habitat, 31 August 2002, DEH 2309; same location and habitat, 17 September 2002, DEH 2328; same location and habitat, 18 September 2002, DEH 2331; same location and habitat, 23 February 2003, DEH 2372; same location and habitat, 7 December 2003, DEH 2447; same location and habitat, 11 January 2005, DEH 2549; Waipi'o Valley, scattered in black sand of coastal dunes under Casuarina equisetifolia, 12 November 2001, DEH 2182.

NOTES: The endoperidium of G. fimbriatum averages $17.3 \mathrm{~mm}$ in diameter (10-23 $\mathrm{mm} ; 73$ specimens) and the peristome is finely fimbriate-fibrillose and indistinctly delimited. This medium to large species often grows in clusters or scattered groups in black sand mixed with vegetative debris under coastal coconuts and coastal Casuarina. The expanded fruiting bodies are similar in size and morphology to those of $G$. litchiforme, which grows in the same habitat, but the two can be distinguished easily in that the unexpanded fruiting bodies of $G$. fimbriatum are hypogeous and encrusted with debris, whereas unexpanded fruiting bodies of $G$. litchiforme are epigeous and lack encrusted debris. In addition, the surface of the unexpanded fruiting bodies of $G$. litchiforme is covered with pyramidal tufts of fibrils in an areolate pattern. Geastrum fimbriatum was first reported from the Hawaiian Islands by Hemmes and Desjardin (2002).

5. Geastrum floriforme Vittad., Monograph Lyc.: 23, 1842.

Descriptions: Sunhede (1989), Pegler et al. (1995), Calonge (1998).

SPECIMENS EXAMINED: Hawai'i Island: $\mathrm{Pu}^{\prime} \mathrm{u}$ Huluhulu, on dirt path, 31 December 2003, DEH 2457; same location and habitat, 12 October 2005, DEH 2595; same location and habitat, 14 March 2006, DEH 2613.

NOTEs: Geastrum floriforme was reported from O'ahu by Smith and Ponce de Leon (1982). This small, hygroscopic species is hypogeous until it expands and has considerable adhering debris on the exterior mycelial layer.
The endoperidium is $10-12 \mathrm{~mm}$ diam., furfuraceous, and has an indistinct, finely fibrillose peristome. The relatively thin rays range from 7 to 10 or more in number, are dark brown on their dorsal surface in age, and spread out flat like ray flowers of a sunflower in moist conditions. Geastrum corollinum is a strongly hygroscopic species and Hawaiian populations are of comparable size (endoperidium 10-13 mm diam.), but basidiomes of $G$. corollinum are epigeous with no adhering debris. In European G. corollinum the peristome is rather distinctly delimited, and the species is easily distinguished from $G$. floriforme with its nondelimited peristome. It is not as clear-cut in Hawaiian populations, however, where we find the best distinction is in the presence of adhering debris on the unopened hypogeous basidiomes of $G$. floriforme in comparison with the absence of adhering debris on the unopened epigeous basidiomes of $G$. corollinum.

\section{Geastrum fornicatum (Huds.) Hook., Curtis} Fl. Londin. 4:575, 1821.

Descriptions: Sunhede (1989), Pegler et al. (1995), Calonge (1998), Hemmes and Desjardin (2002).

SPECIMENS EXAMINED: Hawai'i Island: Hāwī Road, scattered in duff under Casuarina equisetifolia, 25 October 2005, DEH 2597; Māhukona, under Prosopis pallida, 26 November 2000, DEH 2034; Puakō, under Prosopis pallida, 19 March 2007, DEH 2685; same location and habitat, 22 December 2007, DEH 2729; same location and habitat, 7 February 2009, DEH 2792; same location and habitat, 19 February 2009, DEH 2797; same location and habitat, 10 August 2009, DEH 2813; Pu'u Huluhulu, scattered to clustered under Acacia koa, 23 November 1998, DEH 1762; Pu'u Lā'au, scattered to clustered under SophoraMyoporum, 24 September 1996, DEH 1260; Saddle Road near Mauna Kea State Park, scattered to clustered under SophoraMyoporum, 17 January 1996, DEH 1271; Pu'u Là'au, scattered to clustered under SophoraMyoporum, 23 November 1998, DEH 1754; same location and habitat, 2 January 1999, DEH 1795; same location and habitat, 2 Jan- 
uary 1998, DEH 1794; same location and habitat, 21 March 2001, DEH 2083; same location and habitat, 15 November 2002, DEH 2345; Saddle Road, on Kona side of Mauna Kea access road, scattered under SophoraMyoporum, 30 January 1996, DEH 1029. Maui: Polipoli, scattered to clustered under Acacia mearnsii, 22 November 1996, DEH 1341.

NoTes: Geastrum fornicatum is found in the drier portions of the Islands under coastal kiawe (Prosopis pallida) along the leeward coasts, and under koa (Acacia koa) and māmane-naio (Myoporum/Sophora) in leeward montane habitats. This is the only species with fornicate basidiomes from these regions and usually appears in large troops of dozens of fruiting bodies. Endoperidia average 12.5 $\mathrm{mm}$ in diameter (10-20 $\mathrm{mm} ; 50$ specimens) and the peristome is tubular and fibrillose. Smith and Ponce De Leon (1982) did not report $G$. fornicatum from the Hawaiian Islands, but they did report a single collection of $G$. quadrifidum DC. ex Pers. from Hawai'i. This specimen, collected by Otto Degener in 1926 and deposited at the New York Botanical Garden, was examined and represents old, poor-quality material of $G$. fornicatum that lacks endoperidia. We have not seen any material of G. quadrifidum from the Hawaiian Islands. Geastrum fornicatum was previously recorded from māmane-naio habitat on Hawai'i Island by Gilbertson et al. (2001) and Hemmes and Desjardin (2002).

7. Geastrum javanicum Lév., Ann. Sci. Nat. Bot., Ser. 3, 5:161, 1846.

Description: Ponce de Leon (1968).

SPECIMENS EXAMINED: Hawai'i Island: MacKenzie Park, clustered in duff under Casuarina equisetifolia, 1 October 1998, DEH 1720; same location and habitat, 24 November 1998, DEH 1763; MacKenzie Park, clustered on fallen fronds under Cocos nucifera, 28 October 2000, DEH 2003; same location and habitat, 12 October 2001, DEH 2151; same location and habitat, 14 November 2001, DEH 2187; same location and habitat, $31 \mathrm{Au}-$ gust 2002, DEH 2312; same location and habitat, 17 September 2002, DEH 2329; same location and habitat, 18 November 2003, DEH 2438; same location and habitat, 7 December 2003, DEH 2449; same location and habitat, 6 October 2005, DEH 2593. O'ahu: clustered in composted wood chips, 31 January 2010, DEH 2811.

Notes: Unexpanded fruiting bodies of Geastrum javanicum are medium sized, globose, and epigeous with no adhering debris. When expanded, the dark brown endoperidia that average $12.9 \mathrm{~mm}$ in diameter $(8-17 \mathrm{~mm}$; 27 specimens) contrast with the lighter pseudoparenchymatous layer of the expanded rays. Clusters of basidiomes held together by a thick, underlying subiculose mycelium appear on and around scenescent coconut fronds at MacKenzie Park on Hawai' $i$ or in composted wood chips at Koko Crater Botanical Garden on $\mathrm{O}^{\prime}$ ahu. This subiculose mycelium is unique to this species in the Hawaiian Islands and aids in its easy recognition. Geastrum javanicum was reported by Smith and Ponce de Leon (1982) from O'ahu growing under Leucaena leucocephala.

\section{Geastrum litchiforme Desjardin \& Hemmes, n. sp.}

\section{Figure $1 A-E$ \\ MycoBank MB 519175}

Geastrum aff. welwitschii Mont. Hemmes and Desjardin, 2002:86.

LATIN DESCRIPTION: Basidiomata juvene epigaeum, nonfornicatum, ad clausum globulare vel depresse globulare, 22-30 mm altum, $27-40 \mathrm{~mm}$ latum. Exoperidium apertum 50$70 \mathrm{~mm}$ latum in 8-10 radios acutos, recurvos fissum, nonhygroscopicum; stratum myceliale atrobrunneum, pyramidale-squamosum; stratum myceliale et stratum fibrillosum deciduum; stratum pseudoparenchymaticum satis tenue (1-2 mm), griseobrunneum. Endoperidium sessile, globulare, 20-30 $\mathrm{mm}$ latum, pruinosum, griseobrunneum. Peristomium nondelimitatum, fibrillosum. Gleba atrobrunnea. Basidiosporae globulare, 3.2-3.8 $\mu \mathrm{m}$ latae, verrucosae, brunnea.

TyPe MATERial: Holotype: Hawai'i Island, MacKenzie Park, scattered to clustered in duff under Casuarina equisetifolia, 15 Sep- 

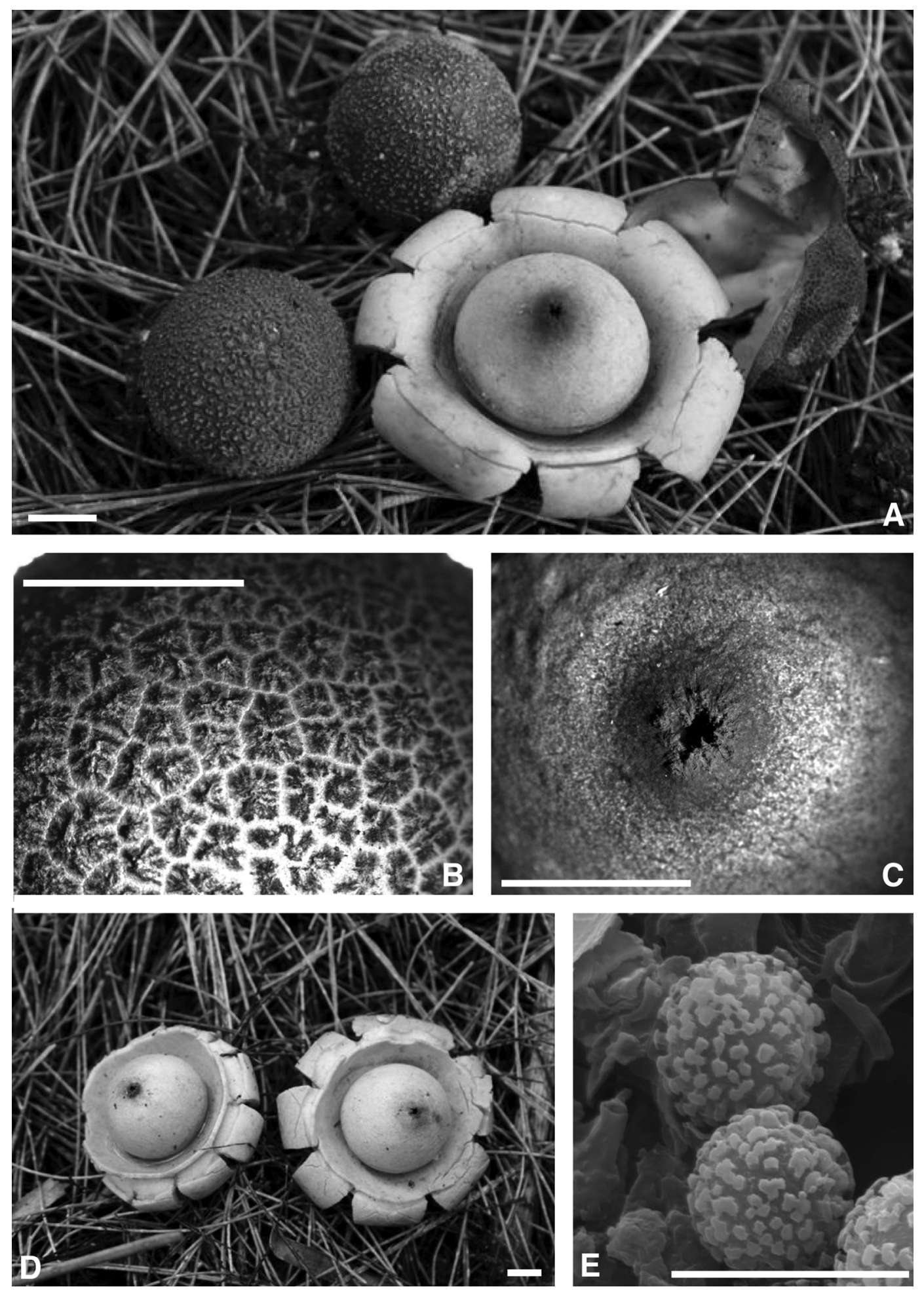
tember 2005, collected by D. E. Hemmes, DEH 2583 (SFSU).

DESCRIPTION: Unexpanded basidiomes 22$30 \mathrm{~mm}$ tall $\times 27-40 \mathrm{~mm}$ diam. $(x=26.5 \times 33.5$ $\mathrm{mm}, n=15$ specimens), globose or subglobose to depressed-globose, epigeous, lacking encrusting debris, attached to the substrate by fine white rhizoids; surface (mycelial layer) covered with small pyramidal tufts of fibers that produce an areolate pattern (Figure 1A) similar to the surface of a lychee fruit; dark brown (6-8F4-8) overall; odor of crushed unexpanded basidiomes strong, similar to that of bok choy (Chinese cabbage). Mycelial layer easily separable from the expanding basidiome, very thin and papery, remaining as a cuplike structure (Figure 1A); nonfornicate. Expanded basidiomes $50-70 \mathrm{~mm}$ in diameter, splitting into 8-10 rays, saccate; rays nonhygroscopic, somewhat recurved, often splitting to form a collarlike structure surrounding the endoperidial body (Figure 1D). Pseudoparenchymatous layer fleshy, 1-2 $\mathrm{mm}$ thick, grayish brown (7E3-4) to brown (6F6). Endoperidium sessile, without an apophysis, globose, 20-30 $\mathrm{mm}$ in diameter $(x=24.7 \mathrm{~mm}$ diam.; $n=46$ specimens), smooth, minutely pruinose, grayish brown (6-7E3-4). Peristome flattened, fibrillose-fimbriate, dark brown, not distinctly delimited. Mature gleba dark brown.

Basidiospores globose, 3.2-3.8 $\mu \mathrm{m}$ diam. $\left(x_{r}=3.51-3.53 \mu \mathrm{m}, n=25, s=5\right)$, finely verrucose, verrucae very low, crowded, brown, thick-walled. Basidia 10-14 × 7-9 $\mu \mathrm{m}$, broadly clavate to subvesiculose, 4-7 sterigmate (mostly 6), hyaline, basally clamped; interspersed with many broadly clavate to clavatemucronate or bladderlike cells 8-18 $\mu \mathrm{m}$ diam., hyaline, inamyloid, thin-walled. Subbasidial byphae 1-2.5 $\mu \mathrm{m}$ diam., cylindrical, hyaline, inamyloid, thin-walled, clamped. Hyphae of tramal plates similar to subbasidial hyphae but parallel and up to $4 \mathrm{~mm}$ diam. Columella byphae in upper part and adjacent to gleba in- terwoven, 1-2.5 $\mu \mathrm{m}$ diam., cylindrical, hyaline, inamyloid, thin-walled; columella hyphae near base of columella $1.5-5 \mu \mathrm{m}$ diam., parallel, hyaline, inamyloid, thin- to thickwalled. Capillitial hyphae (2.5-)4-7 $\mu \mathrm{m}$ diam., cylindrical, very long, unbranched, coarsely roughened, pale grayish brown to dark brown, dextrinoid, thick-walled $(0.5-2.5 \mu \mathrm{m})$, often with very narrow lumen. Endoperidial byphae interwoven, 3-7.5 $\mu \mathrm{m}$ diam., cylindrical, smooth or very weakly roughened, hyaline to pale yellowish brown, inamyloid, thick-walled (0.8-4 $\mu \mathrm{m})$; protruding hyphae common, scattered, 5.5-9 $\mu \mathrm{m}$ diam., irregularly cylindrical to sinuous, often narrowed toward the obtuse tip, pale yellowish brown, inamyloid, thick-walled $(2.5-4 \mu \mathrm{m})$. Peristome byphae subparallel to intertwined, 4-8 $\mu \mathrm{m}$ diam., subcylindrical to sinuous with the tip narrowed to a fine point, smooth, pale yellowish brown, inamyloid, thick-walled $(1.5-3.5 \mu \mathrm{m})$, lumen nearly occluded. Pseudoparenchymatous layer composed of inflated, bladderlike cells $12-24(-30) \mu \mathrm{m}$ diam., hyaline to pale yellow, inamyloid, thin-walled; with protruding hyphae $6.5-11.5 \mu \mathrm{m}$ diam., cylindrical to subclavate, yellow, inamyloid, thick-walled (3$4.8 \mu \mathrm{m}$ ) with lumen nearly occluded. Mycelial layer composed of tufts of subparallel hyphae irregular in outline to aculeate, with a broad base and apically narrowed to a fine point, sinuous, 9-20 $\mu \mathrm{m}$ at broadest area, smooth or roughened, pale yellowish brown, inamyloid, thick-walled $(1-2.5 \mu \mathrm{m})$; inside of dehiscent cups composed of loosely interwoven hyphae 4.5-10 $\mu \mathrm{m}$ diam., covered with an amorphous layer of crystalline matter.

HABIT, HABITAT, AND KNOWN DISTRIBUTION: Scattered to gregarious in duff under coastal Casuarina (Casuarina equisetifolia) or on coconut fronds and coconuts (Cocos nucifera) in coastal coconut groves at MacKenzie Park, Puna District; James Kealoha Beach Park, Hilo; and Leleiwi Beach Park, Hilo.

Figure 1. Features of Geastrum litchiforme Desjardin \& Hemmes, n. sp. (A) Unexpanded and expanded basidiomes growing in duff under Casuarina equisetifolia. Note the tufted areolate pattern on the surface of the unexpanded basidiomes and the husk or outer layer of the exoperidium on the right that easily separates from the expanded basidiome. $(B)$ Higher magnification of the pyramidal tufts and areolate pattern on the surface of the exoperidium. $(C)$ A finely fibrillose-fimbriate peristome blackened with dark brown spores. $(D)$ Mature basidiomes where the rays have systematically broken to form a cup around the endoperidium, much like basidiomes of Geastrum triplex. (E) Scanning electron micrograph of basidiospores. Scale bars for $A-D=1 \mathrm{~cm}$; for $E=1 \mu \mathrm{m}$. 
SPECIMENS EXAMINED: Hawai'i Island: Hilo, James Kealoha Park, clustered in duff under Casuarina equisetifolia, 21 October 2001, DEH 2167; same location and habitat, 7 December 2001, DEH 2204; same location and habitat, 8 October 2002, DEH 2342; same location and habitat, 1 November 2002, DEH 2361; Hilo, Leleiwi, scattered and clustered in duff under Casuarina equisetifolia, 28 October 2000, DEH 2001; Hilo, University of Hawai'i campus, Loulu Garden, 16 August 1995, DEH 865; MacKenzie Park, scattered to clustered in duff under Casuarina equisetifolia, 22 January 1994, DEH 410; same location and habitat, 18 December 1994, DEH 669; same location and habitat, 27 February 1996, DEH 1033; same location and habitat, $6 \mathrm{Au}-$ gust 1996, DEH 1193; same location and habitat, 19 August 1996, DEH 1212; same location and habitat, 28 October 2000, DEH 2000; same location and habitat, 19 February 2001, DEH 2070; same location and habitat, 11 January 2005, DEH 2544; same location and habitat, 11 January 2005, DEH 2545; same location and habitat, 15 September 2005, DEH 2583 (holotype: SFSU); MacKenzie Park, scattered and clustered on coconut and coconut frond debris under Cocos nucifera, 16 January 2000, DEH 1923; same location and habitat, 7 November 2000, DEH 2018; same location and habitat, 12 October 2001, DEH 2155; same location and habitat, 9 November 2001, DEH 2173; same location and habitat, 16 November 2001, DEH 2194; same location and habitat, 11 December 2001, DEH 2212; same location and habitat, 22 January 2002, DEH 2245; same location and habitat, 31 August 2002, DEH 2308; same location and habitat, 18 September 2002, DEH 2332; same location and habitat, 15 September 2005, DEH 2585; same location and habitat, 29 October 2005, DEH 2603; same location and habitat, 15 December 2005, DEH 2610; same location and habitat, 16 January 2007, DEH 2681; same location and habitat, 2 February 2008, DEH 2755.

EтyMology: Litchi forme, from the similarity of the size and surface texture of unexpanded basidiomes to lychee fruit.

Notes: Unexpanded basidiomes of $G$. litchiforme are flattened-globose and have dis- tinctive dark brown pyramidal tufts of fibrils in an areolate pattern on the outer surface of the unexpanded peridium (mycelial layer) that resembles a lychee fruit in surface texture. The tufts are composed of irregularly sinuous, aculeate, thick-walled terminal cells that are apically narrowed to a fine point. In addition, the mycelial layer is easily separated from the basidiome during development and expansion and remains as a paper-thin cuplike structure. The fibrillose-fimbriate peristome is indistinctly delimited and characteristically dark brown as if air-brushed. This large species, currently vouchered only from Hawai'i Island, has a strong odor similar to that of bok choy, especially when unexpanded basidiomes are broken open. It is commonly encountered in duff in coastal Casuarina groves. Geastrum litchiforme was first reported from the Hawaiian Islands as Geastrum aff. welwitschii by Hemmes and Desjardin (2002). Geastrum welwitschii Mont. differs from G. litchiforme in being truly fornicate, in lacking the characteristic lycheelike exoperidial surface ornamentation, and in having larger $(4.5-5 \mu \mathrm{m}$ diam.) basidiospores with fewer, larger, and more coalescent verrucae (compare Figure $1 D$ with Fig. $212 D-F$ of Sunhede [1989]).

In Hawai'i, G. litchiforme may be confused with $G$. triplex. Both species form epigeous basidiomes of comparable sizes (unexpanded and expanded), have saccate exoperidial bodies, sessile endoperidial bodies with fibrillose peristomes, and rays in which the pseudoparenchymatous layer cracks and forms a collarlike structure surrounding the endoperidial body (Figure 1D). Geastrum triplex differs in forming globose-mammiliform or onion-shaped unexpanded basidiomes with a felted-scaly mycelial layer, and a distinct peristome delimited by a white zone.

9. Geastrum minimum Schwein., Schr. Naturf. Ges. Leipzig 1:58, 1822.

Descriptions: Sunhede (1989), Pegler et al. (1995), Calonge (1998).

SPECIMENS EXAMINED: Hawai'i Island: Kapoho (Green Lake), in duff under Casuarina equisetifolia, 6 August 1996, DEH 1196; MacKenzie Park, in duff under Casuarina 
equisetifolia, 19 August 1996, DEH 1213; same location and habitat, 7 November 2000, DEH 2017; same location and habitat, 16 November 2001, DEH 2195; same location and habitat, 11 December 2001, DEH 2211; same location and habitat, 8 November 2007, DEH 2714; Pāhoa, Mike Au's farm, in duff under Cupressus lusitanica, 10 October 1995, DEH 895; same location and habitat, 10 November 2000, DEH 2021; same location and habitat, 16 November 2001, DEH 2193; Pu'u Lā'au, scattered in dry grass, 21 October 1997, DEH 1568; same location and habitat, 23 November 1998, DEH 1753; same location and habitat, 12 October 2001, DEH 2154; same location and habitat, 31 May 2004, DEH 2484; same location and habitat, 29 November 2004, DEH 2539; same location and habitat, September 2005, DEH 2573; same location and habitat, 20 April 2006, DEH 2616; same location and habitat, 15 January 2007, DEH 2678; same location and habitat, 15 July 2009, DEH 2799; same location and habitat, 10 August 2009, DEH 2811; Saddle Road on Kona side of Mauna Kea access road, scattered in soil among cypress tussocks in māmane-naio grasslands, 30 January 1996, DEH 1028.

notes: The distinctly delimited and finely fibrillose peristome, nonhygroscopic rays, and tiny, stalked endoperidium averaging 7.9 $\mathrm{mm}$ in diameter (4-12 $\mathrm{mm}$; 64 specimens) are diagnostic of this species. Geastrum minimum is found in the dry māmane-naio leeward regions of Mauna Kea on Hawai'i Island and in duff under coastal Casuarina and Cupressus. This species was reported from Hawai'i and O'ahu by Smith and Ponce de Leon (1982) and Gilbertson et al. (2001).

10. Geastrum morganii Lloyd, Mycol. Notes 8:80, 1901.

Description: Sunhede (1989).

SPECIMENS EXAMINED: Hawaili Island: $\mathrm{Pu}^{\prime} \mathrm{u}$ Huluhulu, scattered in grass along trail, 31 December 2003, DEH 2454; same location and habitat, 1 January 2004, DEH 2461.

Notes: Geastrum morganii is similar in size and morphology to G. triplex and G. reticulatum. All are large species and have unex- panded basidiomes that are onion-shaped with a distinct papilla, and in all three the rays have a tendency to crack near the endoperidial body, forming a collar or cuplike structure. The three species can be readily distinguished by the different texture of the surface of the unexpanded fruiting bodies and the structure of the peristome. The outer surface of primordia of G. morganii is reddish brown and evenly felted, whereas the surface of primordia of $G$. triplex is brown with scattered scales. Geastrum reticulatum has the characteristic reticulated pattern created by lines of raised hyphae. The peristome of G. morganii is irregularly plicate with well-developed folds and no distinct delimitation, whereas the peristome of $G$. triplex is fibrillose and usually distinctly delimited by a circle of lighter color. The peristome of $G$. reticulatum is strongly plicate, conical, and usually slightly sunken into the endoperidium. Geastrum morganii has only been found under koa (Acacia koa) at $\mathrm{Pu}^{\prime} \mathrm{u} \mathrm{Hu}-$ luhulu on Hawai'i. What was reported as Geastrum aff. morganii by Hemmes and Desjardin (2002) represents the new species $G$. reticulatum (see discussion at no. 12 ).

11. Geastrum pectinatum Pers., Syn. Meth. Fung. (Göttingen) 1:132, 1801.

Descriptions: Sunhede (1989), Pegler et al. (1995), Calonge (1998), Hemmes and Desjardin (2002).

SPECIMENS EXAMINED: Hawai'i Island: MacKenzie Park, in duff under Casuarina equisetifolia, 24 October 1989, DEH 105; same location and habitat, 25 October 1989, DEH 106; same location and habitat, 15 February 1994, DEH 422; same location and habitat, 28 March 1994, DEH 440; same location and habitat, 22 January 2002, DEH 2247; same location and habitat, 19 November 2003, DEH 2448; same location and habitat, 11 January 2005, DEH 2547; same location and habitat, 18 November 2003, DEH 2437; same location and habitat, 1 March 2007, DEH 2687; same location and habitat, 14 December 2007, DEH 2735. Lāna'i: Kō'ele, under Cupressus, 6 January 2007, DEH 2672; same location and habitat, 28 December 2009, DEH 2810. 

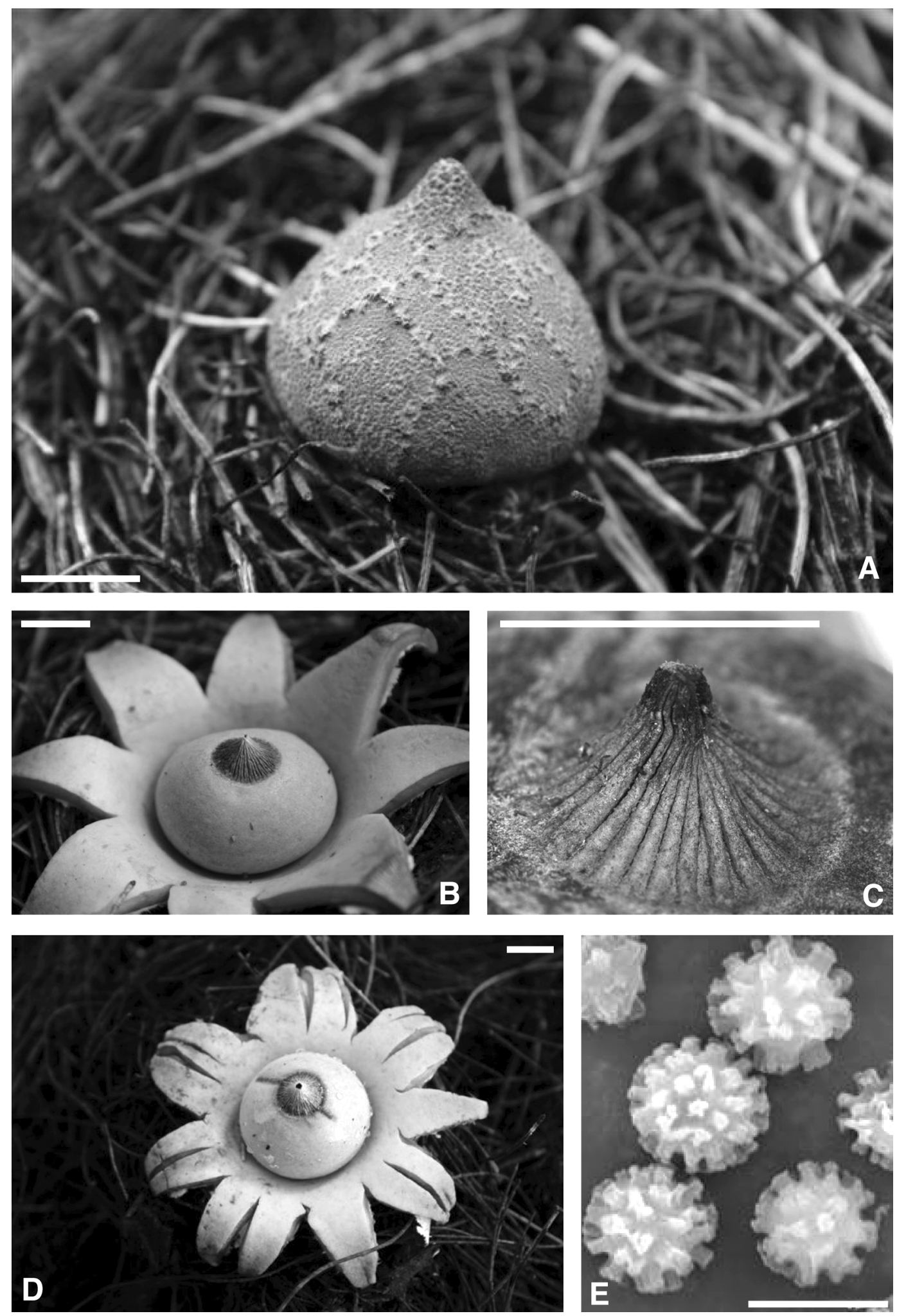
Notes: Basidiomes of Geastrum pectinatum are most commonly found in duff under coastal Casuarina and groves of Cupressus. The endoperidium of this species, like that of $G$. berkeleyi, is perched on a distinct stalk with a well-developed apophysis at the base. Geastrum pectinatum, however, has distinct folds on the base of the endoperidium, whereas $G$. berkeleyi has none. The endoperidium of $G$. pectinatum is usually globose, averages 18.0 $\mathrm{mm}$ in diameter (10-27 mm; 24 specimens) and in fresh specimens has a white, pruinose covering over a lead gray or bluish gray color. In contrast, the endoperidium of $G$. berkeleyi is depressed-globose, averages $17.1 \mathrm{~mm}$ in diameter (9-23 mm; 63 specimens), and is coarsely roughened to verrucose and brown overall. The peristomes of both species are acutely conical and strongly plicate. Geastrum schmidelii is also similar to G. pectinatum, but the former is a much smaller species (endoperidium 6-14 $\mathrm{mm}$ diam.) with a glabrous endoperidium and shorter stalk. Geastrum pectinatum was reported from $\mathrm{O}^{\prime}$ ahu and Ni'ihau by Smith and Ponce de Leon (1982) and from O'ahu and Hawai'i by Hemmes and Desjar$\operatorname{din}(2002)$.

\section{Geastrum reticulatum Desjardin \&} Hemmes, n. sp.

Figure $2 A-E$

MycoBank MB 519176

Geastrum aff. morganii Lloyd. Hemmes and Desjardin, 2002:135.

LATIN DESCRIPTION: Basidiomata juvene epigaeum, nonfornicatum, ad clausum obturbinatum, 26-40 $\mathrm{mm}$ altum, 25-32 $\mathrm{mm}$ latum. Exoperidium apertum $50-75 \mathrm{~mm}$ latum in $7-8(-11)$ radios acutos, recurvos fissum, nonhygroscopicum; stratum myceliale aurantiobrunneum vel atrobrunneum, furfuraceum vel reticulatum; stratum pseudoparenchymaticum 2-3 mm crassum, griseoaurantiacum vel brunneoaurantiacum. Endoperidium sessile, globulare, 15-26 mm latum, glabrum, griseobrunneum. Peristomium conicum, 2-6 mm altum, 5-9 $\mathrm{mm}$ latum, delimitatum, plicatum, atrobrunneum. Gleba atrobrunnea. Basidiosporae globulare, 4.5-5.5 $\mu \mathrm{m}$ latae, verrucosae, brunnea.

TyPe MATERial: Holotype: Hawai'i Island, MacKenzie Park, scattered in duff under Casuarina equisetifolia, 6 October 2005, collected by D. E. Hemmes, DEH 2592 (SFSU).

DESCRIPTION: Unexpanded basidiomes 26$40 \mathrm{~mm}$ tall $\times 25-32 \mathrm{~mm}$ in diameter $(x=$ $32.5 \times 30.2 \mathrm{~mm} ; n=10$ specimens), obturbinate to onion-shaped, epigeous, lacking encrusting debris; surface furfuraceous to reticulate, orangish brown (7D4) to brown or dark brown (7-8F5-8); ornamentation composed of a network of raised hairs (Figure $2 A$ ) forming diamond-shaped or polygonal areas up to $10 \mathrm{~mm}$ diameter. Expanded basidiome 50-75 $\mathrm{mm}$ diameter, splitting into $7-8(-11)$ rays; rays nonhygroscopic, arched, sometimes recurved under the basidiome (Figure 2B). Pseudoparenchymatous layer fleshy, 2-3 mm thick, grayish orange $(5 \mathrm{~B} 3-4)$ to brownish orange (6C4), commonly splitting at the margin of the exoperidial disk and becoming raised into a conspicuous collar. Endoperidium sessile, without an apophysis, saccate, globose, $15-26 \mathrm{~mm}$ diameter $(x=21.9 \mathrm{~mm} ; n=25$ specimens), smooth, glabrous, grayish brown (6-7C-D3-4). Peristome conical, 2-6 mm tall $\times 5-9 \mathrm{~mm}$ diam., strongly plicate with 30-40 ridges, distinctly delimited, margin slightly sunken, dark brown (6-7F6-8). Mature gleba dark brown (6F6).

Basidiospores globose, 4.5-5.5 $\mu \mathrm{m}$ diam. $\left(x_{r}=4.85-5.1 \mu \mathrm{m}, n=25, s=5\right)$ including ornamentation, brown; ornamentation of apically rounded, columnar processes up to

Figure 2. Features of Geastrum reticulatum Desjardin \& Hemmes, n. sp. (A) Unexpanded basidiome growing in duff under Casuarina equisetifolia. Note the characteristic reticulated pattern of raised hairs on the surface. $(B)$ An expanded basidiome illustrating the conical, plicate, dark brown peristome. $(C)$ Higher magnification of the peristome showing the plications. $(D)$ A basidiome that has just expanded. $(E)$ Scanning electron micrograph of basidiospores. Scale bars for $A-D=1 \mathrm{~cm}$; for $\mathrm{E}=1 \mu \mathrm{m}$. 
$0.7 \mu \mathrm{m}$ tall, rather broad and widely spaced. Basidia short-clavate, 4-7 sterigmate (mostly 6-7), basally clamped. Subbasidial byphae 1-2 $\mu \mathrm{m}$ diam., cylindrical, often inflated adjacent to clamp connection, interwoven, branched, hyaline, inamyloid, thin-walled. Hyphae of the tramal plates similar to the subbasidial hyphae but parallel and up to $4 \mu \mathrm{m}$ diam. Columella byphae in upper part and adjacent to gleba 1-3 $\mu \mathrm{m}$ diam., hyaline, inamyloid, thin-walled; columella hyphae near base of columella 1.5-4 $\mu \mathrm{m}$ diam., parallel, hyaline, inamyloid, thin- to thick-walled. Capillitial byphae 1.5-4 $\mu \mathrm{m}$ diam., cylindrical, unbranched, smooth, brown, dextrinoid, thick-walled $(0.5-1.6 \mu \mathrm{m})$, often with very narrow lumen. Endoperidial byphae interwoven, 3.8-6 $\mu \mathrm{m}$ diam., cylindrical, smooth or roughened, subhyaline to pale yellowish brown, inamyloid, thick-walled $(0.5-2.2 \mu \mathrm{m})$; protruding hyphae absent; terminal cells often subclavate, up to $8 \mu \mathrm{m}$ diam. Peristome byphae subparallel, 3-7 $\mu \mathrm{m}$ diam., sinuous, smooth, yellowish brown, dextrinoid, thick-walled (1.2-3 $\mu \mathrm{m})$, lumen nearly occluded, tips narrowed and obtuse. Pseudoparenchymatous layer composed of inflated, bladderlike cells 16-36 $\mu \mathrm{m}$ diam., yellowish brown, inamyloid, thin-walled. Mycelial layer composed of interwoven, sinuous hyphae 3.2-7 $\mu \mathrm{m}$ diam., yellowish brown, inamyloid to dextrinoid, thick-walled $(1-2.5 \mu \mathrm{m})$; terminal cells irregular, swollen to clavate or lobed, 12-24 $\mu \mathrm{m}$ diam., some bladderlike up to 40 $\mu \mathrm{m}$ diam., others tapered to a narrow tip like the capillitial hyphae, inamyloid to dextrinoid, thin- to thick-walled.

HABIT, HABITAT, AND KNOWN DISTRIBUTION: Scattered in duff under coastal "ironwoods" (Casuarina equisetifolia) at MacKenzie Park, Puna District, Hawai'i Island, in leaf mulch in the mixed native forest of koa/'ōhi'a (Acacia koa/Metrosideros polymorpha) and alien strawberry guava (Psidium cattleianum) along the Nu'alolo, Awa'awapuhi, and 'Ohelo Berry Flats trails, Kōke'e State Park, Kaua'i, and under slash pines at Kamakou, Moloka'i.

SPECIMENS EXAMINED: Hawai'i Island: MacKenzie Park, scattered in duff under $\mathrm{Ca}$ suarina equisetifolia, 7 December 1993, DEH 342; same location and habitat, 27 February 1996, DEH 1032; same location and habitat,
28 September 2000, DEH 1999; same location and habitat, 14 November 2001, DEH 2189; same location and habitat, 22 January 2002, DEH 2246; same location and habitat, 11 January 2005, DEH 2551; same location and habitat, 6 October 2005, DEH 2592 (holotype: SFSU); same location and habitat, 29 October 2005, DEH 2600; same location and habitat, 13 December 2005, DEH 2609; same location and habitat, 7 December 2006, DEH 2661; same location and habitat, 9 January 2007, DEH 2674; same location and habitat, 8 November 2007, DEH 2719; same location and habitat, 2 February 2008, DEH 2753. Kaua'i: Kōke'e, Nu'alolo Trail, scattered on ground in leaves under Acacia koa and Psidium cattleianum, 7 January 1994, DEH 358; same location and habitat, 8 January 1996, DEH 959 and D. E. Desjardin 6365; same location and habitat, 4 January 1995, DEH 690; same location and habitat, 7 January 1997, DEH 1423; Kōke'e, Awa'awapuhi Trail, 5 January 2008, DEH 2747; Mākaha Ridge Trail, scattered on ground under Eucalyptus, 6 January 1997, DEH 1413. Moloka'i: Kamakou Forest Preserve, scattered on ground in duff under Pinus, 2 January 1996, DEH 988.

etymology: Reticulatum, refering to the widely spread reticulate network of raised hairs on the surface of the unexpanded basidiome.

Notes: Geastrum reticulatum is one of the larger earthstars found in Hawai' $i$ (endoperidia average $22 \mathrm{~mm}$ diam.) and is distinguished by onion-shaped, brown to orangish brown primordia with a raised, reticulate network of hairs on the outer surface that gives the species epithet. The saccate endoperidium features a conical, plicate peristome. This species is easily distinguished from G. litchiforme, G. fimbriatum, and G. triplex, which are of comparable size, because the latter three species have fibrillose-fimbriate peristomes. The rays of $G$. reticulatum break near their base, forming a collar or cup around the endoperidium, much like in $G$. litchiforme and $G$. triplex. Geastrum morganii is similar to $G$. reticulatum in forming onion-shaped unexpanded basidiomes with a prominent umbo, but differs in other macromorphological features. Geastrum morganii differs in forming 
reddish brown unexpanded basidiomes that lack the reticulated pattern of raised hairs on the surface, and the peristome is formed from folds rather than distinct plications. Geastrum setiferum Baseia is also similar in overall morphology but differs in forming globose unexpanded basidiomes with squamose (not reticulate) exoperidial surface, a setose endoperidium, fibrillose to sulcate peristome, and smaller basidiospores (2.5-3 $\mu \mathrm{m}$ diam. [Baseia and Milanez 2002]). Hemmes and Desjardin (2002) reported G. reticulatum (as Geastrum aff. morganii) from under karakanut (Corynocarpus laevigatus), koa, and 'ōhi'a (Metrosideros polymorpha) along the $\mathrm{Nu}^{\text {'alolo Trail at }}$ Kōke'e State Park on Kaua'i.

13. Geastrum rufescens Pers., Syn. Meth. Fung. (Göttingen) 1:134, 1801.

Descriptions: Sunhede (1989), Pegler et al. (1995), Calonge (1998).

SPECIMENS EXAMINED: Hawai'i Island: Hilo, bayfront, clustered in composted wood chips under monkeypod trees, Pithecellobium saman, 6 December 2001, DEH 2203; same location and habitat, 10 December 2001, DEH 2210; same location and habitat, 15 December 2001, DEH 2214; same location and habitat, 28 August 2002, DEH 2305; same location and habitat, 14 September 2002, DEH 2324.

NOTES: Unexpanded fruiting bodies of Geastrum rufescens are globose, somewhat hypogeous, have little encrusting litter on the surface, and appear in coalescent clusters. Expanded fruiting bodies are distinguished by the pink to reddish brown color of the pseudoparenchymatous layer of the extended rays, and an indistinctly delimited, fibrillosefimbriate peristome on an endoperidial body with a short pedicel (best observed when the pseudoparenchymatous layer has dried). This species is superficially similar to G. fimbriatum, but the reddish pseudoparenchymatous layer of $G$. rufescens and its habit of growing in coalescing clusters is distinctive. In addition, the endoperidial body of $G$. fimbriatum is sessile, and the basidiospores are smaller (3.5-4 $\mu \mathrm{m}$ diam. versus 5-6 $\mu \mathrm{m}$ diam. in $G$. rufescens). Geastrum rufescens has been collected only in composted wood chips at the bayfront in Hilo on Hawai'i Island.

14. Geastrum saccatum Fr., Syst. Mycol. 3:16, 1829.

Descriptions: Sunhede (1989), Calonge (1998).

SPECIMENS EXAMINED: Hawai'i Island: MacKenzie Park, in duff under Casuarina, 14 December 2007, DEH 2734; Pu'u Lā'au, scattered in soil under Sophora-Myoporum, 26 August 1997, DEH 1518; same location and habitat, scattered in soil, 21 October 1997, DEH 1569; Waipi'o Valley, scattered in black sand in dunes under Casuarina equisetifolia, 12 November 2001, DEH 2181; same location and habitat, 3 September 2002, DEH 2315; same location and habitat, 8 July 2006, DEH 2619. Kaua'i: Kukuiolono Park, Kalāheo, under Eucalyptus, 3 January 2008, DEH 2743. O'ahu: Keolu Hills, Kailua, scattered in soil under koa haole, Leucaena leucocephala, 26 March 2002, DEH 2256; same location and habitat, 10 September 2002, DEH 2335; same location and habitat, 5 March 2003, DEH 2375; same location and habitat, 12 July 2004, DEH 2494; same location and habitat, $5 \mathrm{Au}-$ gust 2004, DEH 2497 and 2498.

Notes: Unexpanded basidiomes of Geastrum saccatum are small to medium sized, onion-shaped, epigeous, and have no encrusting debris. The well-delimited fibrillose peristome, nonhygroscopic rays, and sessile, saccate endoperidium are diagnostic. Basidiomes are found in the dry māmane-naio (SophoraMyoporum) forests on the leeward side of Mauna Kea, in windward haole koa thickets (Leucaena leucocephala) on O'ahu, and in sand dunes along the windward coasts of Hawai' $i$ Island under ironwood (Casuarina equisetifolia). Tiny specimens of $G$. saccatum with endoperidia averaging only $2-6 \mathrm{~mm}$ in diameter were found at Keolu Hills, Kailua, O'ahu, after heavy rain. The unexpanded primordia of these specimens appeared to have been disturbed by erosion and then developed when still at a small size. The species was reported from O'ahu by Smith and Ponce de Leon (1982) and from Hawai'i Island by Gilbertson et al. (2001). 
15. Geastrum schmidelii Vittad., Monograph Lyc.: 12, 1842.

Descriptions: Sunhede (1989), Pegler et al. (1995).

SPECIMENS EXAMINED: Hawai'i Island: Puakō, scattered in encrusted leaf and twig debris under coastal kiawe, Prosopis pallida, 24 February 2007, DEH 2687; same location and habitat, 19 March 2007, DEH 2690; same location and habitat, 22 December 2007, DEH 2731; same location and habitat, 2 February 2009, DEH 2790; same location and habitat, 19 February 2009, DEH 2795. Lana'i: Shipwreck Beach, scattered in encrusted leaf and twig debris under coastal kiawe, Prosopis pallida, 27 December 2009, DEH 2808.

NoTEs: Basidiomes of $G$. schmidelii are initially hypogeous, encrusted with debris, and expand to small fruiting bodies $20-37 \mathrm{~mm}$ in diameter with 6-9 arched rays. The endoperidia are stalked, finely pruinose when fresh to glabrous in age, and range from 6 to $14 \mathrm{~mm}$ in diameter (avg. $8.8 \mathrm{~mm} ; 36$ specimens). An apophysis is present on some endoperidia but not on others, and the peristome is plicate with no obvious delimitation at the edge. This species is found near the shoreline in sandy leaf litter under coastal kiawe (Prosopis pallida). This is the first report of G. schmidelii from the Hawaiian Islands.

16. Geastrum striatum DC, in Lamarck \& de Candolle, Fl. Franç., ed. 3 (Paris) 2:267, 1805. (1998).

Descriptions: Sunhede (1989), Calonge

SPECIMENS EXAMINED: O'ahu: Keolu Hills, scattered under haole koa, Leucaena leucocephala, 4 December 2003, DEH 2446; same location and habitat, 6 January 2004, DEH 2480; same location and habitat, 12 September 2004, DEH 2492; same location and habitat, 5 August 2004, DEH 2499 and 2500.

Notes: Unexpanded basidiomes of Geastrum striatum are mostly hypogeous and encrusted with adhering debris. The endoperidium of expanded basidiomes is covered with a whitish layer of crystalline material overlaying a bluish surface color, has a conical, strongly plicate peristome, and is prominently stalked with a distinct apophysis that forms a ringlike collar. Geastrum pectinatum is a similar species, but the latter has folds or plications on the apophysis and lacks the distinctive collar. Geastrum striatum grows under haole koa (Leucaena) at Keolu Hills on the windward side of $\mathrm{O}^{\prime} \mathrm{ahu}$, in the same habitat as $G$. saccatum. This is the first report of $G$. striatum from the Hawaiian Islands.

17. Geastrum triplex Jungh., Tijdschr. Nat. Gesch. Physiol. 7:287, 1840.

Descriptions: Sunhede (1989), Pegler et al. (1995), Calonge (1998).

SPECIMENS EXAMINED: Hawai' $i$ Island: Keaukaha, scattered in leaf mulch, 27 June 2003, DEH 2424; same location and habitat, 14 August 2003, DEH 2429; same location and habitat, 25 April 2004, DEH 2480; same location and habitat, 28 November 2004, DEH 2538; same location and habitat, 9 August 2005, DEH 2561; same location and habitat, 13 September 2005, DEH 2576; same location and habitat, 25 September 2006, DEH 2626; same location and habitat, 6 October 2006, DEH 2634; Kīpuka Kī, scattered in leaf mulch, 14 March 2007, DEH 2686; MacKenzie Park, scattered to clustered in duff of Casuarina equisetifolia, 27 October 2004, DEH 2530; same location and habitat, 4 December 2004, DEH 2542; same location and habitat, 11 January 2005, DEH 2546; same location and habitat, 11 January 2005, DEH 2548; same location and habitat, 15 September 2005, DEH 2582; same location and habitat, 29 October 2005, DEH 2602; same location and habitat, 7 December 2006, DEH 2659; same location and habitat, 7 December 2006, DEH 2660; same location and habitat, 2 February 2008, DEH 2754; MacKenzie Park, scattered under coconut, 3 October 2006, DEH 2629; Pu'u Huluhulu, scattered in deep soil and leaf mulch under Acacia koa, 12 October 1998, DEH 1733; same location and habitat, 11 November 2000, DEH 2024; same location and habitat, 26 November 2000, DEH 2033; same location and habitat, 20 November 2003, DEH 2444; same location and habitat, 12 December 2003, DEH 2453; same location and habitat, 27 
September 2005, DEH 2591; University of Hawai'i, Hilo, Agriculture farm, scattered to clustered in wood chips, 17 November 2004, DEH 2537. Moloka'i: Hālawa Valley, scattered in leaf mulch under black wattle (Acacia mearnsii) and Christmas berry (Schinus terebinthifolia), 4 January 2007, DEH 2668. O'ahu: Wahiawā Botanical Garden, scattered in leaf mulch, 24 November 2002, DEH 2354.

Notes: Geastrum triplex can be locally abundant under coastal Casuarina and coastal coconut groves, and in alien wet windward forests. The unexpanded fruiting bodies are onion-shaped, epigeous, lack adhering debris, and are usually covered with small brown, felted scales that help distinguish this species from morphologically similar taxa. The endoperidia have an acute fibrillose peristome that is usually delimited by a lighter color. There is a wide range in basidiome size of various populations of $G$. triplex, with some populations forming large endoperidia averaging $21.6 \mathrm{~mm}$ in diameter (50 specimens) and other populations with small endoperidia averaging $13.9 \mathrm{~mm}$ in diameter (50 specimens). For a comparison with $G$. litchiforme, see the Notes for that species.

Smith and Ponce de Leon (1982) reported Geastrum indicum (Klotsch) Rauchert from Kaua'i, Maui, and Ni'ihau. Sunhede (1989) provided an extensive nomenclatural discussion of $G$. indicum and considered the epithet a nomen dubium. We accept the material reported as $G$. indicum from the Hawaiian Islands to represent $G$. triplex, making this species the most common and widespread earthstar in the archipelago.

18. Geastrum velutinum Morgan, J. Cincinnati Soc. Nat. Hist. 18:38, 1895.

DESCRIPTIONS: Lloyd 1902, Hemmes and Desjardin 2002.

SPECIMENS EXAMINED: Hawaili Island: Kipuka at 21.0 mile marker, Saddle Road, clustered under Acacia koa, 2 January 1998, DEH 1793; Kipuka Puaulu, Hawai'i Volcanoes National Park, on ground under Acacia koa, 28 October 2000, DEH 1998. Kaua'i: Kōke'e, Nu'alolo Trail, in clusters under $A c a-$ cia koa, 8 January 1996, DEH 961 and D. E. Desjardin 6366; Kōke'e, Awa'awapuhi Trail, scattered under Acacia koa, 6 January 2008, DEH 2779; Mākaha Ridge Road, in clusters under Acacia koa, 10 January 1996, DEH 972.

Notes: Geastrum velutinum has been found along the Nu'alolo and Awa'awapuhi trails at Kōke'e, Kaua'i, and in high-elevation kīpukas on the Big Island. This species is associated with mixed native-alien forests dominated by koa (Acacia koa) and has been found only at higher elevations, approximately 1,000-1,500 $\mathrm{m}$. The very dark brown to nearly black, velutinous exoperidium covering unexpanded, epigeous basidiomes, and fibrillose peristome that is well delimited by a dark ring are diagnostic features. Geastrum velutinum was first reported from Hawai'i by Hemmes and Desjardin (2002), and our material matches quite nicely that from Samoa reported by Lloyd (1902).

\section{Geastrum xerophilum Long ex Desjardin,} n. sp.

"Geaster xerophilus" Long, Mycologia 34:13, 1942, nom. inval.

MycoBank MB 519177

Long (1942) described Geaster xerophilus without Latin diagnosis, constituting an invalid binomial (Art. 36.1). The epithet is validated herein with inclusion of a Latin diagnosis, reference to an original description in Long's (1942) protologue, and citation of a holotype specimen and its place of deposition (Arts. 36, 37, 45).

LATIN DESCRIPTION: Basidiomata juvene hypogaeum, nonfornicatum, ad clausum subglobulare vel depresse globulare, $10-20 \mathrm{~mm}$ latum. Exoperidium apertum $10-40 \mathrm{~mm}$ latum in 7-12 radios acutos, recurvos fissum; stratum myceliale arena adhaerens; stratum pseudoparenchymaticum bubalinum vel cinnamomeum. Endoperidium subsessile vel pedicellate, subglobulare vel depresse globulare, 10-20 mm latum, saccatum, furfuraceum, bubalinum vel pallide-griseum. Peristomium nondelimitatum, sulcatum. Gleba brunnea. Basidiosporae globulare, 4.5-5.5 $\mu \mathrm{m}$ latae, verrucosae, brunnea. 
type material: Holotype: New Mexico, Dona Ana County, Joranada Experimental Range, 12 November 1938, collected by W. H. Long, no. 8285 (BPI 731707!). This is the specimen indicated by Long (1942) as the type specimen, viz., " 8 plants no. 8285 Type."

Descriptions: Long (1942), Ponce de Leon (1968).

SPECIMENS exAMINED: Hawai'i: Pu'u Lā'au, scattered under Sophora-Myoporum, 21 October 1997, DEH 1567; same location and habitat, 21 October 1997, DEH 1604; same location and habitat, 23 November 1998, DEH 1753; same location and habitat, 23 November 1998, DEH 1755; Saddle Road on Kona side of Mauna Kea access road, 6,000 $\mathrm{ft} .[1,800 \mathrm{~m}]$ elev., scattered in soil under Sophora-Myoporum, 30 January 1996, DEH 1030. O'ahu: Keolu Hills, scattered in soil under Leucaena leucocephala, 5 August 2004, DEH 2502.

NOTES: Geastrum xerophilum is one of two species from the māmane-naio habitat with a sulcate peristome, along with $G$. campestre. Geastrum campestre is a strongly hygroscopic species, whereas G. xerophilum is nonhygroscopic. Geastrum xerophilum was reported from O'ahu by Smith and Ponce de Leon (1982) and from māmane-naio habitat on Hawai'i Island by Gilbertson et al. (2001).

Long (1942) published the species without Latin diagnosis and it was not validated by Ponce de Leon (1968) in his revision of the genus Geastrum. This well-circumscribed species of xerophytic habitats is formally validated herein. Ponce de Leon (1968) accepted Geaster pluriosteus Long \& Stouffer as a synonym of $G$. xerophilum, and the latter species was validly published with Latin diagnosis in 1948 , giving it potential priority over the invalid Geastrum xerophilum. We do not accept these two taxa as conspecific. Geastrum pluriosteum (orthographic error corrected) differs in forming sessile endoperidia lacking a pedicel, has fewer rays (only 5-6 per basidiome), larger basidiospores (5.5-7 $\mu \mathrm{m}$ diam.), and 1-3 poorly differentiated, apparently nonsulcate peristomes per basidiome (Long and Stouffer 1948).
20. Myriostoma coliforme (With.: Pers.) Corda, Anleit. Stud. Mykol., Prag: 131, 1842.

Descriptions: Sunhede (1989), Pegler et al. (1995), Calonge (1998).

SPECIMENS EXAMINED: Hawai'i Island: Kalōpā Park, scattered in leaf mulch, 13 December 2007, DEH 2737; Kilohana, scattered in soil, 2 July 1996, DEH 1144; Manukā Natural Area Reserve, scattered in leaves under Metrosideros polymorpha, 20 January 2000, DEH 1931; same location and habitat, 12 September 2000, DEH 1987; Manukā Wayside Park, scattered in leaves under alien trees, 9 November 1999, DEH 1858; same location and habitat, 15 December 1999, DEH 1881; same location and habitat, 12 September 2000, DEH 1986; same location and habitat, 3 July 2004, DEH 2490; Pu'u Lā'au, scattered in soil under naio, 24 September 1996, DEH 1255; Pu'u Lā'au, scattered in dirt, 23 September 1997, DEH 1537; $\mathrm{Pu}^{\prime} u \mathrm{La}$ ' $a u$ Cabin, scattered in powdery soil in shade of māmane and naio, 26 August 1997, DEH 1516; $\mathrm{Pu}^{\prime} \mathrm{u}$ Huluhulu, scattered in leaves under Acacia koa, 12 October 1998, DEH 1732; same location and habitat, 22 November 1998, DEH 1751; same location and habitat, 31 December 2003, DEH 2456; same location and habitat, 13 September 2005, DEH 2575; Saddle Road near Mauna Kea State Park, scattered in soil under māmane and naio, no date, DEH 1382; Saddle Road at $31 \mathrm{~km}$ marker, scattered in soil, 20 August 1996, B. A. Perry 059. Lana'i: Kō‘ele, scattered in duff under Cupressus, 6 January 2007, DEH 2673.

NOTES: Myriostoma coliforme is readily identified because of the numerous stomata in the endoperidium that is elevated above the rays by several stalks. The species can be found under māmane-naio on the dry leeward slopes of Mauna Kea and is frequently found at Manukā Wayside Park on the Kona side of Hawai'i Island under a number of alien trees in the arboretum and in the adjacent dry 'ōhi'a forest. The species was reported from māmane-naio habitat on Hawai'i Island by Smith and Ponce de Leon (1982) and Gilbertson et al. (2001). 
DISCUSSION

The substantial number of Geastrum species reported herein from the Hawaiian Islands is undoubtedly due to the wide range of habitats on each island, ranging from wet windward vegetation zones with an excess of $500 \mathrm{~cm}$ of rain annually, to dry leeward regions with as little as $20 \mathrm{~cm}$ of annual precipitation. Many species, such as G. berkeleyi and G. triplex, can be found in a variety of habitats including the duff under coastal Casuarina, under Cupressus lusitanica, and in leaf mulch in Psidium cattleianum thickets. In comparison, G. schmidelii has a preferred habitat in the duff under leeward kiawe (Prosopis pallida) groves both at Puakō on Hawai'i Island and at Shipwreck Beach on Lāna'i, and G. velutinum has been found exclusively at high elevations (1,000-1,500 m) at Kōke'e on Kaua'i and in kippukas on Hawai'i Island in native forests dominated by Acacia $k o a$. Several species are associated mainly with dry upland native māmane-naio habitat (Gilbertson et al. 2001).

All of the Geastrum species reported by Smith and Ponce de Leon (1982 [with clarification below]) were recollected, and nine additional species are added to the checklist of species from the Hawaiian Islands. Although Smith and Ponce de Leon (1982) reported G. quadrifidum, we have verified that their material represents $G$. fornicatum, which is relatively common in drier montane and leeward areas. Also, G. indicum, as listed by Smith and Ponce de Leon (1982), is considered a nomen dubium, and the correct designation for this taxon is G. triplex.

The newly described Geastrum reticulatum is widespread from coastal Casuarina on the Big Island at MacKenzie Park to the Kōke'e region of Kaua'i, where this species is found associated with koa trees. Unfortunately, we have not encountered $G$. reticulatum on any of the islands in between. Geastrum litchiforme has been collected only at MacKenzie Park on Hawai'i Island associated with coastal Casuarina, although we have seen a photograph of a taxon from the Judd Trail on O'ahu that may represent this new species. The habitats of both of these newly described species are heavily disturbed by feral pigs.
Species determinations in this paper were based entirely on morphological characters. DNA sequence data have shown that the genus Geastrum belongs to the Geastrales in the Phallomycetidae (Hosaka et al. 2007). Sequencing of the worldwide Geastrum species, including those from Hawai' $i$, is currently under way (Kentaro Hosaka, National Museum of Nature and Science, Ibaraki, Japan) and should help elucidate the relationships of the various species.

\section{ACKNOWLEDGMENTS}

We thank Helen Hemmes, Russell Shioshita, Erica Jenkins, Colin Patrick, and Ilko Stoytchev for help in our search for earthstars throughout the Hawaiian Islands. Tina Carvalho of the Biological EM Facility at University of Hawai'i at Mānoa is thanked for providing the scanning electron microscope photos of basidiospores and Brian Perry for helping design the plates.

\section{Literature Cited}

Baseia, I. G., and A. I. Milanez. 2002. Geastrum setiferum (Gasteromycetes): A new species with a setose endoperidium. Mycotaxon 84:135-139.

Calonge, F. D. 1998. Gasteromycetes, I. Lycoperdales, Nidulareales, Phallales, Sclerodermatales, Tulostomatales. Flora Mycol. Iberica 3:1-271.

Gilbertson, R. L., D. E. Desjardin, J. D. Rogers, and D. E. Hemmes. 2001. Fungi from the mamane-naio vegetation zone of Hawai'i. Fungal Divers. 6:35-69.

Hemmes, D. E., and D. E. Desjardin. 2002. Mushrooms of Hawai'i. Ten Speed Press, Berkeley/Toronto.

Hosaka, K., S. T. Bates, R. E. Beever, M. A. Castellano, W. Colgan III, L. S. Domínguez, E. R. Nouhra, J. Geml, A. J. Giachini, S. R. Kenney, N. B. Simpson, J. W. Spatafora, and J. M. Trappe. 2007 (2006). Molecular phylogenetics of the gomphoidphalloid fungi with an establishment of the new subclass Phallomycetidae and two new orders. Mycologia 98:949-959. 
Lloyd, C. G. 1902. The Geastrae. Bull. Lloyd Libr. Bot. 5 (Mycol. Ser. 2): 1-44.

Long, W. H. 1942. Studies in the Gasteromycetes: IV. A new species of Geaster. Mycologia 34:13-16.

Long, W. H., and D. J. Stouffer. 1948. Studies in the Gasteromycetes: XVI. The Geastraceae of the southwestern United States. Mycologia 40:547-585.

Pegler, D. N., T. Laessöe, and B. M. Spooner. 1995. British puffballs, earthstars, and stinkhorns. Royal Botanic Gardens, Kew.
Ponce de Leon, P. 1968. A revision of the family Geastraceae. Fieldiana Bot. 31:303349.

Smith, C. W., and P. Ponce de Leon. 1982. Hawaiian geastroid fungi. Mycologia 74:712-717.

Sunhede, S. 1989. Geastraceae (Basidiomycotina): Morphology, ecology, and systematics with special emphasis on the North European species. Synopsis Fungorum 1, Oslo, Norway. 